Copyright (C) 2018 by Academic Publishing House Researcher

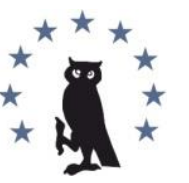

Published in the Russian Federation

European Researcher. Series A

Has been issued since 2010.

ISSN 2219-8229

E-ISSN 2224-0136

2018, 9(2): 107-112

DOI: $10.13187 /$ er.2018.2.107

www.erjournal.ru

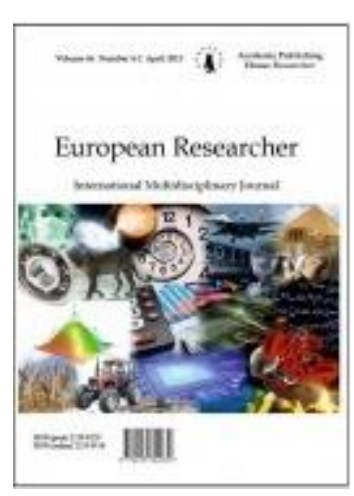

\title{
Transgender in India: Identified by Law Discriminated by the Society
}

\author{
Sribas Goswami a , *, Sushweta Karmakar a

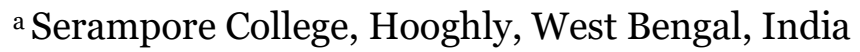

\begin{abstract}
Transgender is an important topic for research nowadays in academia. These people are fighting for their rights immensely and it is coming only through the verdicts of various courts of India be it the apex court or the lower courts. We the commoners make their lives unbearable irrespective of the verdicts they are looked down by us. The term transgender is differentiated by us, the very so called social and sensible being, we differentiate transgender from the male and the female and we created the so called "third gender". Though India is progressing and advancing in leaps and bounds, she is moving towards accepting the third gender by only the virtue of court verdict. This paper is an attempt to discuss various problematic issues face by transgender in India.

Keywords: transgender, education, disadvantage group, marginalization, discrimination, harassment.

\section{Introduction}

The definitions of gender and sex have commonly been confused with one another and therefore have often been thoughtlessly misused. The third are people whose sexual orientation or sexual activity or appearance is somewhat different from the prevailed birth sex of the society. According to the American Psychological Association, sex refers to the biological orientation of a person, their physical reproductive makeup which is male or female. Gender therefore is the actions, interactions, and feelings one expresses either as man/boy or girl/woman.

The transgender's existence in the society can be dated back to the Mahabharata or rather from the onset of the human civilization. Transgender were respected earlier in the society but situation has changed and they face discrimination and harassment with the passage of time (Bilodeau, 2005).

In this paper we will find out how various types of marginalization transgender individuals experiences harassments in their daily life; it can be societal, political, educational, and economical and even can be work place. They are denied their basic human rights to live life according to their own wish (Bilodeau, 2005).

So if we really want these people to enjoy their basic rights and include the transgender population into the main stream of India , court verdict is definitely not the ultimate answer, we need to identify the cluster of population who are still having discomfort in this respect and make them understand. India is a democratic country and Indian constitution ensures to every citizen opportunities to grow and attain their potential, irrespective of caste, religion or gender. Everyone has a gender identity. In India three gender can be identified; male, female and transgender.
\end{abstract}

\footnotetext{
${ }^{*}$ Corresponding author

E-mail addresses: sribasgoswami@gmail.com (S. Goswami)
} 
Gender is the social way of discriminating one person from another which is purely based on his/her behavior attitude of social being and most prominently the appearance plays a major role. Transgender are people or rather transgender is the term used for the people whose appearance, characteristics, physical attributes and behavior differs from the so called birth sex (male/female). Transgender people commonly fights a war which is from within, when they are unable to match their physical appearance with their behavior and at that point of time they discriminate themselves from the society and on the reverse side the society also cant accepts them and awards them the term "Hijra".

"Sex is what you are born with, gender is what you recognize and sexuality is what you discover" - This was the comment made by one of the Hijra.

Sociologist Candace West and Don Zimmerman about their argument that "gender was less a component of identity-fixed, static, that we take with us into our interactions, but rather the product of those interactions" (Radhakrishnan, 2013).

Emphasizing the social construct of gender they argued that "a person's gender is not simply an aspect of what one is, but more fundamentally, it is something that one does, and does recurrently, in interaction with others."

Transgenderism is one such phenomenon where we are 'transgendering' person. The toils on one's soul is unimaginable, living in a body that is not their own and trying to understand what will make it right, this is the struggle of transgender people. Transgender people have existed in every culture, race and class since the story of human life has been recorded. The contemporary term, transgender, arose in the mid-1990s from the grassroots community of gender-different people. Human rights are basic rights and freedoms which are graduated to a human by virtue of him being a human which can neither be created nor destroyed by any government. It includes the rights to life, liberty, equality, dignity and freedom of thought and expression. Article 21 ensures a person to choose one's gender identity. Determining the right to personal freedom and self determination, the count observed that "the gender to which a person belongs is to be determined by the person concerned." The count has given the people of India the right to gender identity. (Rajkumar, 2016)

India has achieved significant growth in different spheres, like levels of literacy, education health, but still the transgender community is one of the marginalized and vurnerable communities in the country, is seriously lagging behind on human development indices including education (Rajesh, Naveed, 2013). Despite all these advantages and development and (LGBT Bill, supreme court 2014), the life of transgender people is a daily battle with themselves and their society. They are forced to face high levels of stigma in almost every spheres of life. Extreme social exclusion diminishes rather kills one's self esteem and sense of social responsibilities.

\section{Discussion}

\section{Transgender in Indian History:}

Transgender people had been an integral part of Indian Society for centuries. With the onset of the human civilization traces of transgender people is evident. Both history and mythology provides every instance of their presences, which can't be denied and neglected. there was historical evidence of recognition of "third sex" or persons not confirm to male or female gender in near the beginning writings of ancient India.

In fact, there are various rituals and traditions, which are specific to the transgender community, or rather they are incomplete without the presence of these people.

From the mythological text Ramayana we get to know about an incidence which can we put to support our argument about their presence, Shri Rama sanctioned them the power to confer blessings on people on auspicious occasions like child birth and marriages, and also at inaugural functions which was supposed to set the stage for the customs of badhai in which Hijra sings, dance and confer blessings. Their presences are also spelled out in the Kama Sutra and elsewhere as pumsprakritistri-prakrit (female natured), and tritiya-prakrit (thord nature).the transgender also occupied high positions in the Islamic religious institutions, especially in guarding the holy places of Mecca and Medina, they were also able to influence the state decisions and also receive large amount of money to have been closet to king and queens (Carroll,2002).

During the Ottoman empires and the Mughal rule in the Medieval India Transgender played a famous role, they rose to well-known positions as political advisors, administrators, generals as well as guardians .transgender were considered clever ,trustworthy, and fiercely loyal and had free 
access to all places and sections of population, thereby planning a crucial role in the politics of empire building in the Mughal era.

In the beginning of the British period in Indian subcontinent Hijra used to accept protection and benefits by some Indian states through entry into the Hijra community. India was dominated by British who believed transgender were of unpleasant public decency, although British did not accept transgender people whole heartedly, but Indian communities still accept them as respectable figures with magical powers. transgender was not seen as strange until mid 1990s. historical evolution of transgender community in India by M. Michelraj ,Ph.D Research Scholar, Public administration, Department of political Science and public administration, Annamalia university, Tamilnadu.

\section{Constitutional Rights:}

While India has made considerable progress on rights of transgender people in recent years, most remain socially marginalized and deprived of basic rights, including the right to vote, own property, marry, and claim a formal identity through a passport or other government identification. The right of equality before law and equal protection of law is guaranteed under Article 14 and 21 of the Constitution. The right to choose one's gender identity is an essential part to lead a life with dignity which again falls under the ambit of Article 21. Determining the right to personal freedom and self determination, the Court observed that "the gender to which a person belongs is to be determined by the person concerned." The Court has given the people of India the right to gender identity.

Further, they cannot be discriminated against on the ground of gender as it is violation of Articles 14, 15, 16 and 21.

The Court also protects one's gender expression invoked by Article 19 (1) (a) and held that "no restriction can be placed on one's personal appearance or choice of dressing subject to the restrictions contained in article 19(2) of the Constitution".

In spite of all these basic fundamental rights till date they are unable to live a better and free life under the sky, thought the laws, rights grants them permission to have a good life, but still In different parts of the world mainly India they have to fight and cry for their rights in every field (Devor, 2004).

In 2014, the Supreme Court of India ruled that transgender people be recognized as a third gender and enjoy all fundamental rights. The Supreme Court stated: "Transgender persons' right to decide their self-identified gender is also upheld and the Centre and State Governments are directed to grant legal recognition of their gender identity such as male, female or as third gender."

The Union Cabinet approved the Transgender Persons (Protection of Rights) Bill 2016 for introduction in Parliament, and this Bill is expected to bring social, educational and economic empowerment to the transgender community. To a community that has been ostracized and discriminated against for so long, this Bill could mean a chance to live a life of dignity and equality (Michelraj, 2015).

The Bill makes it illegal to force a transgender person to leave residence or village, remove their clothes and parade them naked, force them into begging or any kind of bonded labor. These acts will be punishable with up to two years of imprisonment, along with a fine and also asks for amendments in the law to cover cases of sexual assault on transgender persons. The Bill also criminalizes denying a transgender person access to any public place and causing them any physical or mental harm within and outside the home. It guarantees OBC status to all transgender not born as SC or ST, and entitles them to reservation under the respective categories. The Bill identifies 'Transgender' as the third gender and gives a transgender person the freedom to identify as 'man', 'woman' or 'transgender', independent of surgery/hormones. They cannot be referred to as the 'other' gender or as 'others', but only as transgender. A certificate of identity as a transgender needs to be issued by a state level authority and this certificate should be acceptable as gender identity for any official document like passport, Aadhaar card, etc. It also ensures that transgender persons or transgender children enjoy the right to equality, all human rights, right to life and dignity and personal liberty as guaranteed by the Constitution of India. All government institution shall provide inclusive education and shall not discriminate against any transgender student and also provide transgender students with scholarship, textbooks, hostel accommodations, other facilities and subsidized rates. Additionally, all educational institutions need to have an anti- 
discrimination cell to monitor discrimination against transgender students. The government shall also set up rehabilitation and welfare programmers', information centers etc. for transgender persons and provide necessary orientations to sensitize people in educational institutions and elsewhere (Docter, et.al., 2001).

The Bill instructs law the police to provide every assistance under the law to an aggrieved transgender person, and also to put the person in touch with the nearest organization for rehabilitation of aggrieved transgender persons (Sharma, 2012).

The Bill instructs the government to support and facilitate employment of transgender persons, especially for vocational training and self-employment, provide loans, and to ensure that there is no discrimination against transgender person at workplaces.

Under the provisions in this Bill, transgender persons shall also have equal rights and access to a cultural life, leisure and recreational activities (Lawrence, 2004).

Irrespective to so many judgments and pronouncements by various courts, they have to fight their daily battles, to breathe freely, live enjoyable and think wisely. Though these bills are a medium to bring them to the main scale life and provide them with every opportunity, but still in many parts of India they have to fight their daily battles. If these rights are there to protect them then why they are looked down by the society, why we don't help them to practice their rights, why we can't offer them a good society where they won't be looked down, where they won't be harassed on a first instances and later move to court for a judgment why can't we make the world a better place, where narrow thoughts don't guide us.

\section{Societal Problems of transgender:}

Transgender in India are commonly known as 'Hijra' and they are forced to live in small groups of similar community. They allow new members, i.e. young boys, who are either victim of sexual abuse or have run away from home because of shame. The community often lives in seclusion and follows their own customs. They are deprived from actively participating in political, social, economic and financial sectors, which leaves them with limited options to earn a livelihood. Thus, on account of this, they earn their living by performing in the streets, at ceremonies, begging and even prostitution. These transgender people are well sound to understand the problems of their fellow mates and offer them a place to live and share their feelings which on the other hand the society rejects.

Because of the continuous discrimination, they do not even receive formal education and even if the parents want them to be educated, the schools remain reluctant to admit them. Though by the new pronouncement of the law they are allowed to excise their rights to join school, but the law doesn't look into the harassments which they will face from their fellow mates and teachers after being admitted to any educational institution, there is no body to take this responsibility and so most of them results to be uneducated (Goswami, 2013).

Devoid of any skills or education, consequently they do not get job opportunities. Furthermore, as many government forms recognize only the two genders, Male and Female, has prevented them from benefitting from many schemes, which are otherwise available to other marginalized communities (Seil, 2004).

They are also ridiculed by society, for being different; they are more exposed to face violence and abuse. Lack of protection from the police translates into them being easy targets for money extortions and sex work. Their issues escalate over the health sector as well since many practitioners do not have sufficient knowledge about health issues of sexual minorities, which makes them face barriers while approaching public healthcare. For instance, some of the discrimination reported by the transgender community is as follows: registering them and admitting them in male wards; verbal harassment; denial of medical treatment, etc.

In India there is less space for transgender in social, economical and political spheres; they are unable to get proper benefits from conservative social structures and institutions. They are incapable to use power or to found enjoy citizenship rights at their homes or in society. Social, legal, educational and health services are extremely forceful for a person with a transgender identity. This has prevented them from positioning themselves in the greater society with human potential and dignity (Nuttbrock, et.al., 2002).

Caked in cheap rouge, Kajal, powder and lipstick, they dress in ill-fitting blouses and colorful saris in a deformed parody of womanhood as they roam the busy marketplaces in groups begging 
for some insufficient money. However, begging is not their only source of income. It is an age-old custom in India to have eunuchs bless childbirths, weddings, housewarmings and other auspicious occasions. They are also believed to possess occult powers and their blessings and curses are both considered potent. The study shows that this prejudice is translated into violence, often of a brutal nature, in public spaces, police stations, prisons and even in their homes. The main factor behind the violence is that society is not able to come to terms with the fact that transgender do not conform to the accepted gender divisions. In addition to this, most transgender have a lower middle-class background, which makes them susceptible to harassment by the police and the civic society members. The systematic violence that transgender face is reinforced by the institutions such as the family, media and the medical establishments and is given legitimacy by the legal system (Roy, 2016).

Many transgender proved themselves better than other two genders, those people are inspiration for their own genders as well as other two genders.

Some examples who can be set as an example to others, these following people can be a source of energy and inspiration to others who still hide their face in shame and their family thinks they will be disrespected if people come to know about the presence of transgender person within their family.

\section{Success stories of transgender:}

Laxmi Narayan Tripathi, who fought to convince India's Supreme Court to recognize a "third gender" in 2014. She is now chair and founder of Astitva Trust, Asia's first transgender organization. In recent years one Hijra, Laxmi Narayan Tripathi, has tried to change the onlookers mindset about her community and has made it her mission to bring out the revolution. She was the first transgender person to represent Asia Pacific at the United Nations and has represented her community and India on several international platforms including the World AIDS conference in Toronto.

Shanthi Soundarajan: An Indian runner was born in 1981 in the village of Kathakkurichi in Pudukkottai district of Tamil Nadu, India. Soundarajan, a dalit (Untouchable) by birth belongs to poorest of poor category. She grew up in a small hut devoid of toilet, water or electricity. In 2006, she was chosen to represent India at the Asian Games held in Doha, Qatar. In the 800 meters, Soundarajan took the silver in 2 minutes, 3.16 seconds, beating Viktoriya Yalovtseva of Kazakhstan by 0.03. This win and a subsequent failed gender test lead to Soundarajan becoming embroiled in an ongoing, unresolved debate over the issue of transgender and sports (BBC News, 2006). She was told results indicated that she "does not possess the sexual characteristics of a woman" (BBC News, 2006). Soon after the results of the sex test came out, she was stripped of her silver medal.

\section{Conclusion}

Transgender was given a higher position $\mathrm{n}$ the ancient days and in the olden times even during the Mughal period and they were destined to enjoy privileges in near future ,but sadly none of the vows of olden times are fulfilled now. but now to safe guard them new regulations and rules are being offered by the government even new policies are designed and it is hoped through these their socio-economical status will be uplifted (Beam, 2007).

Transgender suffer from mental health problems like depression and suicidal tendencies. So the society and the doctor must understand what drives them towards these.

As soon as parents are able to identify some problems among their wards they should not create any fuss that leads to the exclusion of the child from the mainstream life, rather they should they should become more caring and protective ,because other than them the whole society will be against the child. Open and accepting spaces for people of different gender or sexual orientations is hardly an unreasonable demand to make, and with the help of programs that help these peoples we can organize some organizations through which we can rectify the behavior of others towards them and provide all with equal opportunity and visibility. We as a society have to learn that there is much more to this and we need to understand or put one clear idea into our mid that transgender are not aliens they are just people to belong to various gender identities or multiple gender attributes. As per 2011 census, there are around 4.9 lakh third genders in the country that faces social discrimination and harassment, the government should work to eradicate the stigma, 
discrimination and human rights violation for the betterment of the transgender community. If these helped are provided with a helping hand which leads to them to the mainstream and better life, then it would enlarge the growth of transgender people that is accepted by all people of India.

\section{References}

Chettiar, 2015 - Chettiar A. (2015). The status of Hijra in civil society. International Journal of Social Science and Humanity, Vol. 5, No. 9.

Bilodeau, 2005 - Bilodeau, B. (2005). Gender, power, and social justice: Transgender students in higher education. Unpublished doctoral dissertation, Michigan State University.

Bilodeau, Renn, 2005 - Bilodeau, B., Renn, K.A. (2005). Analysis of LGBT identity development models and implications for practice. New Directions for Student Services, (111), 25-39.

Beam, 2007 - Beam, C. (2007). Transparent: Love, family and living with Transgender Teenagers. Orlando, FL Harcourt.

Carroll, Gilroy, 2002 - Carroll, L., Gilroy, P.J. (2002). Transgender issues in counselor preparation. Counselor Education \& Supervision, 41(3), 233-242.

Devor, 2004 - Devor, A.H. (2004). Witnessing and mirroring: A fourteen stage model of transsexual identity formation. Journal of Gay \& Lesbian Psychotherapy, 8(3/4), 41-67.

Goswami, 2013 - Goswami, S. (2013). Gender, Slum and Society. Global Journal of human Social Science, Vol. 13 Is. 5, 45-52.

Kimmel, 2004 - Kimmel M.S. (Ed.) (2004). The gendered society reader New York and Oxford: Oxford University Press, 118-131.

Lawrence, 2004 - Lawrence, A.A. (2004). Autogynephilia: A paraphilic model of gender identity disorder. Journal of Gay \& Lesbian Psychotherapy, 8(1/2). 69-87.

Roy, 2016 - Roy, S.N. (2016). Social inclusion of transgender population in India common people's perspective. Kolkata, Vol. 4, Is. 9, 13-19.

Rajkumar, 2016 - Rajkumar (2016). Education of transgender in India: Status and challenges. Haryana, Vol. 6, Is. 11, 15-24.

Michelraj, 2015 - Michelraj, M. (2015). Historical evolution of transgender community in India. Tamil Nadu, Vol. 4 No. 1, 17-19.

Nuttbrock et al., 2002 - Nuttbrock, L., Rosenblum, A, Bluenstein, R. (2002). Transgender identity affirmation and mental health. The International Journal of Transgenderism, 6(4).

Sharma, 2012 - Sharma, P. (2012). Historical Background and Legal Status of Third Gender. Indian Society, Vol. 2.

Radhakrishnan, 2013 - Radhakrishnan, K.S.J. (2013). In the supreme court of India civil original jurisdiction Writ petition(civil) no. 400 of 2012, National Legal Service Authority, Judgment.

Seil, 2004 - Seil, D. (2004). The diagnosis and treatment of transgendered patients. Journal of Gay \& Lesbian Psychotherapy, 8(1/2), 99-116.

Docter, Fleming, 2001 - Docter, R. F., Fleming, J. S. (2001). Measures of transgender behavior. Archives of Sexual Behavior, 20(2), 255-271. 